\title{
La imagen en El Perú Ilustrado (Lima, 1887-1892)
}

L’image dans El Perú Ilustrado (Lima, 1887-1892)

The picture in El Perú Ilustrado (Lima, 1887-1892)

\section{Isabelle Tauzin Castellanos}

\section{OpenEdition}

\section{Journals}

Edición electrónica

URL: http://journals.openedition.org/bifea/6431

DOI: $10.4000 /$ bifea.6431

ISSN: 2076-5827

\section{Editor}

Institut Français d'Études Andines

\section{Edición impresa}

Fecha de publicación: 1 abril 2003

Paginación: 133-149

ISSN: 0303-7495

\section{Referencia electrónica}

Isabelle Tauzin Castellanos, "La imagen en El Perú Ilustrado (Lima, 1887-1892) », Bulletin de I'Institut français d'études andines [En línea], 32 (1) | 2003, Publicado el 08 abril 2003, consultado el 10 diciembre 2020. URL : http://journals.openedition.org/bifea/6431 ; DOI : https://doi.org/10.4000/bifea. 6431

\section{(c) (i) $\odot$}

Les contenus du Bulletin de l'Institut français d'études andines sont mis à disposition selon les termes de la licence Creative Commons Attribution - Pas d'Utilisation Commerciale - Pas de Modification 4.0 International. 


\section{LA IMAGEN EN EL PERU ILUSTRADO (LIMA, 1887-1892)}

Isabelle TAUZIN CASTELLANOS*

\section{Resumen}

El Perú Ilustrado fue la primera revista ilustrada que se publicó en el Perú. Como el conjunto de la prensa peruana del siglo XIX, ese semanario no ha sido objeto de estudios monográficos aunque presenta un material iconográfico de primera importancia. Nuestro análisis se interesa primero por la portada de la revista que tiene un carácter emblemático, pues opone un ideal de progreso a un país considerado arcaíco. Luego vienen los retratos que valoran en especial el modelo del self made man. Va desfilando el Perú de norte a sur, como representación de un mundo encaminado hacia la modernidad. Las leyendas y los comentarios que acompañan los grabados delatan los presupuestos ideológicos del cuerpo de redactores que postergan hasta la última plana la representación de los tipos populares. El Perú Ilustrado resulta así un arma de doble filo, expresión de las ambigüedades del discurso progresista de finales del XIX.

Palabras claves: Perú, siglo XIX, historia cultural, prensa.

L'IMAGE DANS EL PERÚ ILUSTRADO (LIMA, 1887-1892)

\section{Résumé}

El Perú Ilustrado est la première revue illustrée publiée au Pérou. Comme l'ensemble de la presse péruvienne du XIX ${ }^{\mathrm{e}}$ siècle, cet hebdomadaire n' a pas fait l'objet d'études monographiques alors qu'il présente un matériel iconographique de première importance. Notre analyse s'intéresse d'abord au frontispice de la revue qui revêt un caractère emblématique, opposant un idéal de progrès à un pays jugé archaïque. Viennent ensuite les portraits qui valorisent tout particulièrement le modèle du self made man. Le Pérou du Nord au Sud défile dans les pages du journal, représentation d'un monde sur le chemin de la modernité. Les légendes et les commentaires qui accompagnent les gravures révèlent les présupposés idéologiques des rédacteurs, repoussant en dernière page la représentation des types populaires. El Perú Ilustrado s'avère ainsi une arme à double tranchant, expression des ambiguïtés du discours progressiste de la fin du XIX siècle.

Mots clés : Pérou, XIX ${ }^{e}$ siècle, histoire culturelle, presse.

\footnotetext{
${ }^{*}$ Université Michel de Montaigne-Bordeaux 3 Domaine Universitaire 33607 Pessac Cédex. E-mail: ITauzin@aol.com
} 


\title{
THE PICTURE IN EL PERÚ ILUSTRADO (LIMA, 1887-1892)
}

\begin{abstract}
El Perú Ilustrado is the first magazine with illustrations published in Peru in the nineteenth century. Until now it had not been studied, but the illustrations and commentaries it contains are very interesting. This analysis first focuses on the cover of the magazine with its emblematic character that opposes the ideal of progress within a country through to be archaic. Afterwards the analysis focuses on the portraits of celebrities which give special importance to the model of the "self made man". From north to south Peru is represented as a world on the way to modernity. The legends and commentaries that accompany the illustrations reveals the ideological proposal of the magazine editors that leave the representation of popular figures the end of the magazine. The Perú Ilustrado thus is revealed as a two-edged sword, expressing the ambiguities in the discourse of progress prevailing at the end of the 19th century.
\end{abstract}

Key words: Peru, XIX ${ }^{\text {th }}$, cultural history, press.

Después de la tragedia de la Guerra del Pacífico y con el antecedente de El Correo del Perú en los años 1870, El Perú Ilustrado comenzó a circular en Lima en mayo de 1887 sucediendo a Perlas y Flores, un folleto gratuito que en la inmediata posguerra no llegó a cumplir la doble vocación "literaria y comercial" que se asignara. El modelo que seguía El Perú Ilustrado eran las Ilustraciones publicadas en Europa mientras la influencia norteamericana se iba a manifestar en la ideología de la revista (La prensa ilustrada en España-Las Ilustraciones 1850-1920).

El Perú Ilustrado llevó una vida agitada, fue puesto en el Índice en 18901891(1) y dejó de aparecer en 1892 tras un incendio que destruyó la imprenta. Inicialmente sólo costaba 10 céntimos, pero duplicó su precio al cabo de seis meses al mismo tiempo que aumentaba el número de grabados: dos páginas de ilustraciones se agregaron a las cuatro imágenes que tenían los primeros números. Con esa aparición, las ilustraciones dejaron de estar confinadas a la simple caricatura política, y el público lector pudo disponer de imágenes más cercanas a su realidad que las que aparecían en La Ilustración Española y Americana de Madrid o en La Ilustración de Barcelona vendidas en las librerías de Lima.

Poco importaba la identidad de los redactores encargados de reseñar las ilustraciones (2). Había que convertir El Perú Ilustrado en "un agente de adelanto para el país, modesto sí, pero lleno de voluntad y de constancia para colocar su óbolo humilde en el gran depósito del progreso universal" (El Perú Ilustrado, n 41, 18 de febrero de 1888).

(1) El motivo de la prohibición fue la publicación de un cuento titulado Magdala que relataba de forma heterodoxa el encuentro de Cristo con María Magdalena.

(2) Jorge Miguel Amézaga, Zenon Ramírez y Clorinda Matto de Turner, vinculados con el Círculo Literario que animaba Manuel González Prada, asumieron la dirección de El Perú Ilustrado entre 1887 y 1890 . Clorinda Matto de Turner fue quien escribió los editoriales de mayor alcance, reflexionando sobre el papel educativo de la prensa, las presiones sufridas por los periodistas independientes, y otros temas (Tauzin Castellanos, 1990: 201-203). 
El proyecto editorial llevado a cabo por Peter Bacigalupi, un industrial ítalonorteamericano afincado en Lima, fue un desafío económico tanto más arriesgado cuanto que el Perú se hallaba aún postrado por la derrota. El proyecto se convirtió rápidamente en una alianza de intereses gracias a la aparición del taller de litografía de Evaristo San Cristóval, encargado de constituir el fondo iconográfico (3).

Sin embargo, el texto de los primeros números anulaba la imagen al enmarcarla; desempeñaba el papel tradicional de simple ilustración y sólo era un elemento secundario que apenas distraía la mirada de la lectura. Un caso aparte era constituido por el retrato de la primera plana que sí llamaba la atención del lector y aportaba una información remitiendo a un tema de actualidad. Las dos primeras páginas de la revista reseñaban las ilustraciones que el público iba a descubrir más adelante, entre textos literarios y avisos comerciales (4) (Fig. 1).

Historia y geografía peruanas, figuras del pasado y personajes contemporáneos, paisajes, monumentos e industrias desfilaron por primera vez ante la mirada de los cientos de suscriptores con los que contó El Perú Ilustrado apoyándose en una red de distribuidores cada vez más extensa (5).

El objeto del presente estudio es dar una aproximación al contenido iconográfico de El Perú Ilustrado. Por eso vamos a examinar primero las portadas que sirvieron de emblema a la revista de Bacigalupi y luego nos detendremos en la galería de retratos, que configuran el hilo conductor de la obra. En una tercera etapa presentaré los grabados con los que se intentó representar la diversidad del territorio peruano; por último me interesaré por las imágenes que asociaban instrucción y entretenimiento y solían aparecer al final de la revista.

\section{LAS PORTADAS DE EL PERÚ ILUSTRADO}

Para seducir al público que estaba familiarizado con las Ilustraciones españolas e imponer una imagen de la revista, Peter Bacigalupi utilizó los servicios de Evaristo San Cristóval. Debía formular en imágenes el discurso de la revista. La Ilustración Española y Americana, que era la revista de referencia de los lectores peruanos, se anunciaba en 1887 con un paisaje urbano, en el que figuraban todos los estilos arquitectónicos de la península ibérica. La referencia a América, explícita en el título, se limitaba a la evocación de un continente exuberante y primitivo, sin vínculo con los símbolos de la cultura europea que acaparaban el centro de la imagen.

(3) El taller de San Cristóval creció rápidamente. El número de colaboradores que firmaron sus dibujos en El Perú Ilustrado duplicó en el espacio de dos años, pero no se beneficiaron de un reconocimiento público hasta octubre de 1889 cuando Clorinda Matto de Turner asumió la dirección de la revista e hizo figurar los nombres de todos los dibujantes.

(4) Las ilustraciones se distribuían inicialmente en sólo tres páginas; luego aumentó el número de páginas por el crecimiento de las ganancias publicitarias, y la repartición de los grabados dejó de ser siempre la misma; sólo como seña de identidad del semanario, se mantuvo el retrato de la primera plana.

(5) En junio de 1887 el semanario dio una primera lista de 17 agentes ( ${ }^{\circ} 7,25$ de junio de 1887); a los seis meses, el número de distribuidores se había duplicado, siendo el norte y el centro del país los beneficiarios de la expansión ( $\mathrm{n}^{\circ} 26,5$ de noviembre de 1887). 
La primera viñeta de El Perú Ilustrado ocupa la mitad de la página y está rodeada de un marco (Fig. 1). Tiene la apariencia de un cuadro que ofrece al mismo tiempo una puesta en escena y una puesta en abismo. El centro de interés lo conforma un viaducto, portento de ingeniería que desafía un descomunal precipicio. En aquel puente de hierro, símbolo de la tecnología más avanzada de la época, circula un tren que está a punto de entrar en un túnel, imagen de la victoria del hombre sobre la naturaleza inhóspita. Paralelamente, aparece una alegoría del Perú antiguo, bajo la forma de un indio emplumado que desde una rudimentaria oroya parece que se dispone a lanzar una flecha hacia el tren que pasa a todo vapor.

El juego de las proporciones, la inexactitud de la perspectiva, la pequeñez del indio que a pesar de estar en el primer término no es más que un monigote, son elementos que revelan las perspectivas ideológicas de los fundadores de El Perú Ilustrado, que no eran sino las de la clase dirigente. Los lamentables ceramios antropomorfos, la rústica cabaña, las frágiles llamas que sólo pueden cargar unos exiguos bultos, en fin, todo lo
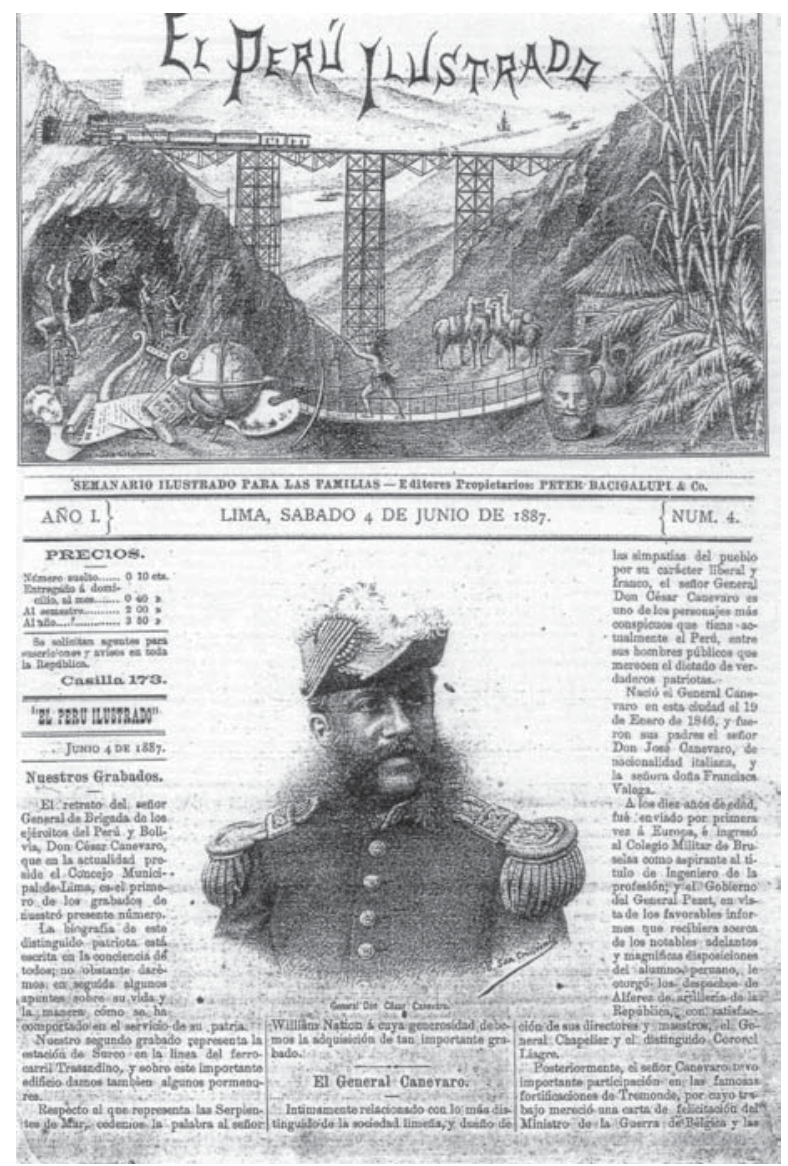

Fig. 1 - El Perú Ilustrado, nº 4, 4 de junio de 1887. 
que alude a la indianidad, sólo puede ser un signo del pasado y la prueba de que lo indígena es un obstáculo al desarrollo del país.

En perfecta oposición y siguiendo un plano simétrico, se destacan los aportes de la civilización europea. Una serie de objetos emblemáticos sobresalen gracias a un trazo bien afirmado: la paleta de un pintor, un busto antiguo, una máscara y una imponente lira, un globo terráqueo y un compás. La literatura está representada de manera bastante curiosa bajo la forma de un libro que lleva como título Industria Minera del Perú al lado de un pergamino en el que se puede leer "Ley de Minas", un texto de ley que fue promulgado en 1887, o sea exacto contemporáneo de la revista.

Por encima de aquel conjunto figura el trabajo en una mina con hombres vestidos y equipados no como mineros peruanos sino como europeos. Así, se va perfilando un país que explota científicamente sus recursos naturales gracias a un sistema de comunicación eficiente que conjuga el ferrocarril victorioso y la luz a gas que brilla en la galería, con el novísimo teléfono que desde la mina extiende sus postes por encima de la cordillera.

El Perú Ilustrado promete sustituir el arcaíco estado de natura por el estado de cultura. Las nuevas tecnologías han de permitir la explotación científica de las riquezas naturales del país haciendo realidad el mito del progreso. Durante cinco años, el "semanario ilustrado destinado a las familias", como se autodenomina la revista, es el adalid de la modernidad, pero con el tiempo van prevaleciendo los intereses económicos y aumentan los avisos comerciales a expensas de las páginas de información.

La portada de El Perú Ilustrado es modificada al cabo de un año. El título pasa a ocupar completamente el primer término y está sobreimpreso sobre el dibujo (Fig. 2). Se han suprimido los elementos artísticos y los emblemas dando paso a una nueva perspectiva: la luz no viene como antes del lejano océano sino de la "I" de "Ilustrado". Los símbolos del progreso han sido ampliados y ahora se hallan a la derecha. La locomotora exhalada a todo vapor sobre un puente de hierro se une a un teléfono a batería para encarnar el progreso y se deja de lado toda representación del Perú antiguo. Los mineros, altos y bien equipados, continúan trabajando con ahínco a la izquierda. El lector de El Perú Ilustrado puede fácilmente identificarse con esos hombres emprendedores y entusiastas que son la negación del pasado y los garantes de la prosperidad de la cual la revista pretende ser al mismo tiempo la expresión y el reflejo.

\section{UNA GALERÍA DE PERUANOS ILUSTRES}

La exaltación de la industria y de la tecnología se encuentra en contradicción con la primera plana de la revista ya que en lugar de presentar una escena de actualidad cada semana se expone el rostro de un personaje ilustre. En ese sentido, El Perú Ilustrado sigue la senda de La Ilustración de Barcelona y de La Galerie contemporaine de París (6).

Esta galería de retratos presenta al lector un arquetipo con el cual pueda identificarse. Por regla general, el retrato coincide con un suceso de actualidad, ya sea

(6) La Galerie Contemporaine publicó cada semana entre 1876 y 1894 una fotografía de una personalidad acompañada con una biografía. 


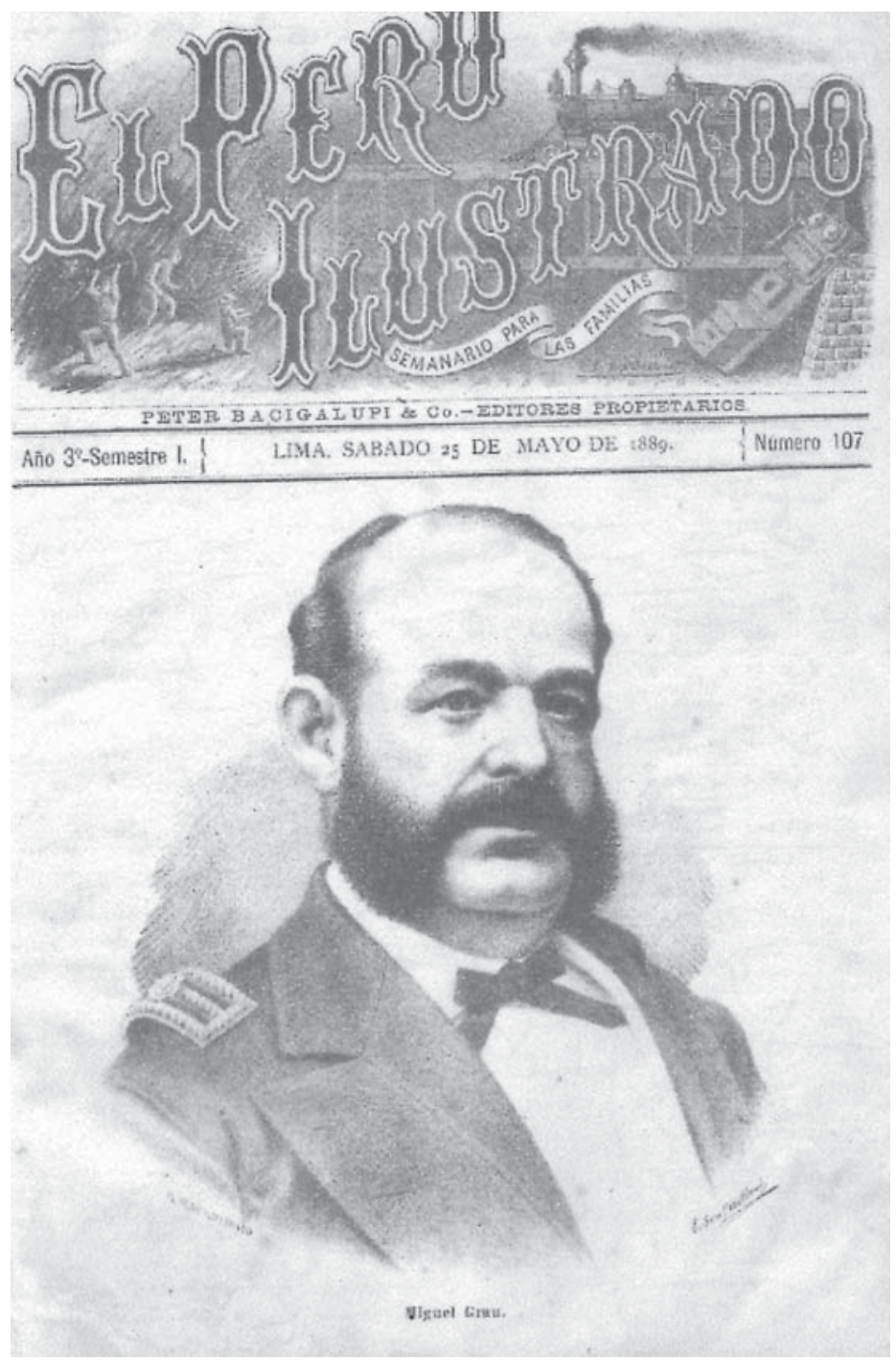

Fig. 2 - $\mathbf{n}^{0}$ 107, 25 de mayo de 1889.

una elección, una nominación o un deceso. El objetivo anunciado en el comentario que acompaña el grabado es rendir homenaje a las personas que han destacado desde la Independencia. Tal galería de personas célebres también tiene como meta la posteridad y pretende ser un legado para la historia al estilo de las clásicas biografías de varones ilustres: "[Queremos] recordar los grandes servicios, las altas dotes de aquellas notabilidades que en las letras o la política, las armas o las ciencias, hayan descoyado [sic] sobre la generalidad haciéndose dignas de universal renombre [...] y estimular a los que aún en el comienzo de una carrera manifiestan prendas superiores", (El Perú 
Ilustrado, $\mathrm{n}^{\circ} 40,11$ de febrero de 1888). Esta galería se dirige a los historiadores de los siglos venideros que valorarán la documentación acumulada: “Así nosotros no hacemos historia sino simplemente consignamos datos, que con el trascurso del tiempo, vendrán a servir en nuestras colecciones de un indicador a manera de diccionario biográfico donde el historiador pueda hallar los puntos culminantes de la vida de los individuos que ocupen un lugar en nuestra galería" (El Perú Ilustrado, n 146, 22 de febrero de 1890).

La variedad de retratos corresponde a la voluntad de atraer y seducir al público lector. Niños (7) y ancianos (8), hombres y mujeres, limeños y provincianos son inmortalizados en una imagen seguida de un corto comentario que precisa su nombre y rango; luego, en las páginas interiores, una biografía completa el retrato del prócer.

La selección toma en cuenta la susceptibilidad del gobierno de turno, lo que explica por ejemplo que en el segundo número aparezca, pocos días después de su muerte, el retrato de la madre del general Cáceres, en aquel entonces Presidente de la República. El general Canevaro, alcalde de Lima, figura también con uniforme de parada y llamativo bicornio, testigo de su elevadísimo grado (Fig. 1). Pero en realidad, por encima de esta evidente voluntad de granjearse la benevolencia del gobierno, se destaca un compromiso constante en favor del liberalismo económico. Los vínculos de las personas que aparecen en la portada con el presidente Manuel Pardo, quien trató de reformar la economía nacional, siempre son puestos de relieve. Incluso, desde la óptica del comentario, pertenecer a una logia (9) parece serun signo más de progreso aunque esta audacia terminará por desaparecer a partir de 1889, una época de campaña electoral y tensión política durante la cual la revista intenta conciliarse con los grupos de presión más importantes del Perú consagrando una página al ejército y a las múltiples actividades del Círculo Militar y otra a la ceremonia de investidura del arzobispo de Lima.

El patriotismo es uno de los argumentos ecuménicos de la revista. Pero los héroes de la guerra del Pacífico (10) y los próceres de la Independencia no son los únicos capaces de dirigir el país por la vía del progreso. Los intelectuales, los juristas (11), los ingenieros y los médicos figuran en las portadas dando así la imagen de una sociedad civil que participa en el progreso universal encarnado en la representación del inventor Thomas A. Edison y de la astrónoma María Mitchell.

La aparición de jóvenes autores peruanos y de escritores latinoamericanos, sobre todo mujeres, amplía el horizonte de la revista, dándole a la vez una dimensión continental y una marcada independencia frente a los cánones literarios europeos. Sólo

(7) Véase por ejemplo el número 107, con fecha 25 de mayo de 1889: ofrece un retrato de Juan C. Montero, "notable pianista nacido en 1877 ".

(8) El número 26 del 5 de noviembre de 1887 rinde homenaje a Francisco Javier Mariátegui, padre fundador de la Independencia, muerto en 1884 a los 91 años.

(9) Es el caso del general Canevaro: "hace poco ha merecido también el honor de ser elegido Gran Maestre de las Logias del Perú", El Perú Ilustrado, n 4.

(10) El retrato de Miguel Grau es presentado el 25 de mayo de 1889 con motivo del décimo aniversario del combate naval de Iquique.

(11) Los retratos de juristas son muy numerosos; citaremos el de José Toribio Pacheco publicado en El Perú Ilustrado el 29 de junio de 1889 más de veinte años después de la muerte de ese especialista del derecho. 
al cabo de dos años y medio va a aparecer un poeta español, Nuñez de Arce, al pie de un autógrafo que parece autentificar el retrato (12).

La lista puede completarse con personajes políticos extranjeros (13), embajadores y, provocación inédita, un sacerdote que no pudo llegar a ser obispo del Cuzco por haberse pronunciado contra el celibato eclesiástico (14). Es de notar que los cantantes de ópera de paso por Lima son objeto de una especial veneración, quizás no desinteresada, si se toma en cuenta que el director de la revista era también dueño del Teatro Municipal. De la misma manera, la extraña aparición del retrato de un virrey español, Pezuela, tal vez pueda explicarse no por un súbito interés por la historia colonial sino más bien por el simple hecho de que la compañía Bacigalupi había puesto en venta el palacio del citado virrey.

El formato de los retratos, en un primer momento ecléctico, terminó por uniformarse, la forma ovalada reemplazó a las imágenes cuadradas o rectangulares. Los bordes difuminados del retrato, que suele aparecer en contrapicado, magnifican al personaje. Las más de las veces la pose suele ser la de un ligero perfil, para evitar la agresividad que representaría la imagen de frente. Ese tipo de grabado, que al principio sólo aparecía en primera página, comenzó a reproducirse luego al interior, cuando la revista aumentó su volumen. La multiplicación de imágenes se explica probablemente por la mejor calidad alcanzada en las litografías y por la habilidad de los redactores al establecer una biografía capaz de inducir en el público el afán de figurar en la revista. Incluso la señoritas que hacían sus pinitos en literatura aceptaban exponer sus rostros en primera plana, lo que constituye un notable cambio en las mentalidades.

La vida y obra de cada persona figura en la segunda o en la tercera página, consignada con énfasis y detalle. Los orígenes provincianos son por regla general puestos de relieve ya que demuestran el pluralismo de la revista, que no se limita a hacer la apología de la alta sociedad de Lima sino que pretende mostrar la vitalidad intelectual de todo el Perú. En la reseña, los rasgos de las personas son pasados por alto, como si bastara con contemplar la litografía (15). La regla general es el uso de eufemismos que deparan más de una sorpresa al lector, como en el caso del músico Manuel de la Cruz

(12) La nota biográfica, redactada por la indigenista Clorinda Matto de Turner, es reveladora de cierta concepción de la literatura: "Nuñez de Arce pertenece al número de los escritores que increpan y admonestan, de los que como nuestro González Prada, hacen crujir su látigo sobre las prevaricaciones sociales, de los que imprimen el hierro candente de su palabra en la frente o en la espalda de grandes malévolos", El Perú Ilustrado, n 126, 5 de octubre de 1889. González Prada expresó en 1887 una opinión muy negativa acerca de Nuñez de Arce.

(13) El retrato oficial de la reina Victoria está reproducido el 25 de junio de 1887 (nº 7); el de Rafael Núñez, presidente de Colombia, aparece el 18 de febrero de 1888 ( $\left.{ }^{\circ}{ }^{\circ} 41\right)$ y el de la emperatriz regenta de Brasil, Isabel Cristina, el 5 de octubre de 1889 ( $\left.{ }^{\circ} 126\right)$.

(14) Se trata de Juan Gualberto Valdivia, cuya vida empieza a ser referida en El Perú Ilustrado ( ${ }^{\circ}$ 121, 31 de agosto de 1889); el lector está pendiente de una continuación en otro número pero el relato queda inconcluso.

(15) La excepción a esta regla se observa para el cusqueño Manuel Suárez: "Su talla no fue elevada. Su color era tostado por el sol de los collados, más moreno que blanco", El Perú Ilustrado, $\mathrm{n}^{\circ} 146,22$ de febrero de 1890. La sensible poetización de esa descripción se debe a la pluma de la igualmente cusqueña Clorinda Matto de Turner. 
Panizo, calificado de "modesto hijo del pueblo", lo que sobreentiende lo oscuro de la piel evidenciado en el retrato. Sin embargo, y a veces a ultranza, el color, las arrugas y otros detalles considerados como taras, son atenuados ofreciendo así la ilusión de la eterna juventud en el retrato presentado al público (16).

Pese a la imagen de pluralismo que intenta vehicular, El Perú Ilustrado valoriza por encima de todo a un personaje particular: el self-made-man, a la imagen y semejanza del director ítalonorteamericano Peter Bacigalupi. El inmigrante o el provinciano que llegó a Lima con los bolsillos vacíos y que gracias a su trabajo y a la tecnología moderna amasó una inmensa fortuna, es el nuevo héroe (17) que se intenta promover como alternativa al clásico modelo del heredero, ese rentista improductivo de la economía peruana. Por eso, el audaz empresario, el capitán de industria llega a equipararse con los héroes caídos por la patria. La comparación de dos retratos puede ilustrar esta orientación: el parecido físico entre el inglés North, uno de los reyes del salitre instalados en Iquique y connotado adversario de los intereses peruanos en 1879 y el Almirante Grau, gloria de la marina de guerra del Perú, es flagrante (Figs. 2 y 3). Ambos benefician del mismo tratamiento, aunque la diferencia reside en el tamaño de las litografías, ya que Grau, que venció en el combate de Iquique en 1879, es víctima de la ironía trágica al aparecer disminuido frente al inglés (18).

El progreso asociado al patriotismo y la cultura vinculada con el comercio se van perfilando como los elementos de base sobre los cuales se afirma la revista de Bacigalupi que a lo largo de sus páginas, pretende dar al lector la ilusión de vivir en un país próspero y dotado de un sinfín de hombres de talento.

\section{UN TERRITORIO EN IMÁGENES}

Los grabados que figuran en las páginas interiores contribuyen a difundir el mismo mensaje. Los paisajes y la naturaleza no son considerados en ningún momento desde un punto de vista estético. El encanto de algunos lugares como Chanchamayo, ideal para la producción de café, forma parte del comentario pero en realidad de lo que se trata es de señalar las dificultades que debe afrontar el pionero para llegar hasta esa región oriental que no cuenta con medios de comunicación modernos: "El dibujo siguiente es la copia de uno de los bellísimos paisajes que se ofrecen a cada paso a los ojos del viajero en nuestra montaña de Chanchamayo, en la que después de haber atravesado las áridas y heladas cumbres de los Andes, se encuentra con toda la exhuberante [sic] flora de los trópicos, con todas las riquezas de la más expléndida [sic] naturaleza, que serán para nosotros casi inútiles mientras no contemos con fáciles vías

(16) Así ocurre con Juana Manuela Gorriti, setentona rejuvenecida en El Perú Ilustrado ( ${ }^{\circ} \quad 11$, 22 de junio de 1889).

(17) El retrato del fotógrafo Artemio Cabieses, colaborador muy activo de El Perú Ilustrado, es presentado de la forma siguiente: "Artemio Cabieses ha luchado, se ha formado por sí mismo y lo que es hoy, lo que posee, no lo debe sino a sus propios esfuerzos, a su voluntad para el trabajo, El Perú Ilustrado, $\mathrm{n}^{\circ} 108,1^{\circ}$ de junio de 1889.

(18) El retrato de North de mayor tamaño fue publicado una semana antes del de Grau ( ${ }^{\circ} 106$, 18 de mayo de 1889). 


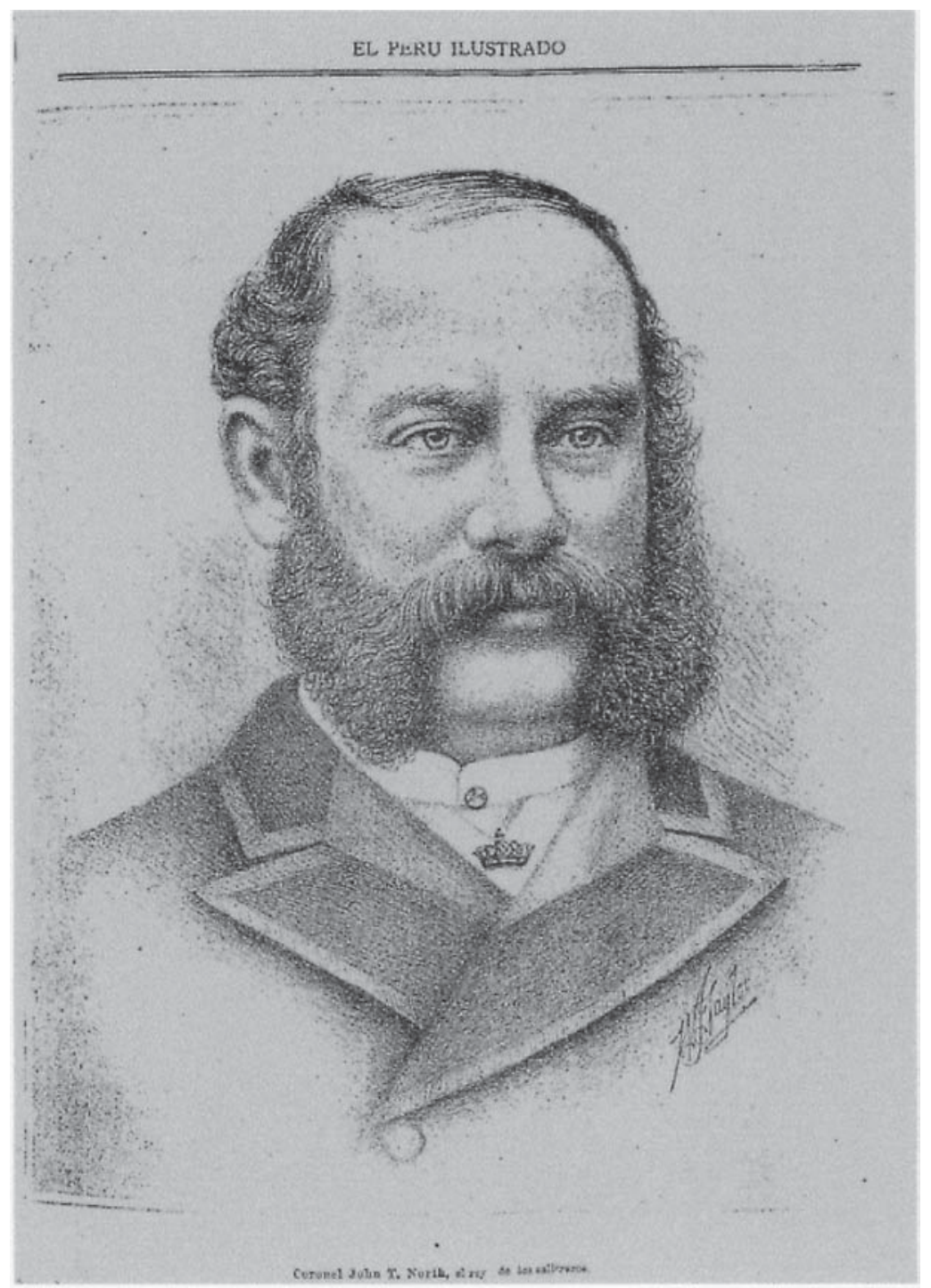

Fig. 3 - no 106, 18 de mayo de 1889.

de comunicación, la carencia de las cuales será la rémora que por mucho tiempo aún se opondrá a nuestro adelanto y a ese bienestar que hoy no es más que dorada ilusión" ( $E l$ Perú Ilustrado, $\mathrm{n}^{\circ}$ 42, 25 de mayo de 1888).

La naturaleza inhóspita nunca es objeto de elogios; la revista prefiere privilegiar las ciudades frente a los espacios inhabitados. Las ciudades pequeñas, como Jauja, Huaraz y hasta Moyobamba, adquieren una imagen concreta gracias a grabados que representan la catedral o la plaza de armas a las que puede reconocer con orgullo el 
público local y que descubre con asombro el lector de otras regiones. La revista ilustrada desempeña de esta manera un papel federativo. Una semana tras otra ofrece una imagen desconocida del Perú al público de Lima que, por vez primera, deja de ser todo el Perú:

"A nuestros lectores del interior de la República suplicamos nos manden fotografías y dibujos de su localidad que puedan ser de interés general. Por las que aceptemos y publiquemos pagaremos un buen precio", (El Perú Ilustrado, $\mathrm{n}^{\circ}$ 7, 25 de junio de 1887).

Por desgracia, los redactores suelen desconocer los lugares representados y tras un comentario sucinto se limitan a insistir sobre la necesidad de construir infraestructuras que pongan un término a la ignorancia y aceleren el desarrollo económico del país.

Lima aparece sobre todo como un centro cultural dotado de establecimientos universitarios y modernos hospitales que son testigos del nivel científico de la ciudad, comparable al de otras metrópolis del continente como Caracas, desde donde escribe un activo corresponsal. Arequipa y Cusco son también objeto de varias ilustraciones. Arequipa, unida a la costa por un ferrocarril, parece ser un buen equilibrio entre tradición y modernidad, la catedral, destruida por un sismo en 1868 es la primera imagen presentada; pero la estación, el puente de piedra casi concluido y el viaducto que se extiende por una fértil llanura completan la representación de la prosperidad de la ciudad, capaz de rivalizar con la capital por ser cuna de eminentes personalidades:

"Tenemos listos numerosos grabados referentes a Arequipa, que iremos publicando a medida que nos sea posible y con alguno de ellos insertaremos la descripción completa de esa ciudad que continuamente agitada, a veces rebelde, vencedora o vencida, siempre es digna de respeto" (El Perú Ilustrado, $\mathrm{n}^{\circ} 106,18$ de mayo de 1889).

Al contrario Cusco sirve de contraejemplo con sus calles desiertas, sus monolitos y ruinas completamente abandonadas. El punto de vista de la redacción frente a la herencia prehispánica aflora a través de dos grabados, el primero, relegado a la última página muestra a un pobre indígena harapiento que contempla, indiferente y perdido, una imponente muralla (El Perú Ilustrado, n 118, 10 de agosto de 1889). El segundo en el mismo número de El Perú Ilustrado expone una oroya y en lugar de alabar el ingenio de la obra, el comentario se limita a señalar los obstáculos que han de afrontar "el comercio, la industria, en una palabra, la civilización."

Las ciudades conquistadas por Chile durante la guerra del Pacífico, como Iquique y Tacna son presentadas en su antiguo esplendor, con calles comerciales y bellas construcciones, sin que se aluda a la ocupación chilena y menos aún a la idea de un desquite (El Perú Ilustrado, ${ }^{\circ}$ 111, 22 de junio de 1889). El Perú Ilustrado exalta la memoria de los héroes caídos por la patria sin plantear reivindicaciones territoriales. Esa actitud, insólita en aquella época agitada por la idea de una revancha, se explica por los compromisos comerciales de Bacigalupi.

Los grabados en los que aparecen otras ciudades latinoamericanas (Caracas, Guatemala, Río, México, etc.) acentúan la impresión de riqueza y variedad, dándole a la revista una fácil aureola de difusión internacional. De esta manera, El Perú Ilustrado 
se va perfilando no sólo como un agente de integración nacional sino también como un factor de unidad y de intercambio con todo el continente.

El Perú Ilustrado no pretende limitarse a servir de carta de presentación de las ciudades apartadas de la capital; su meta fundamental es exaltar los símbolos de la modernidad. En lugares remotos, la civilización avanza, como lo demuestran las ilustraciones de las grandes obras que terminarán por unir el país. El viaducto de Chaupichaca, un tramo de carretera entre Tarma y Chanchamayo (El Perú Ilustrado, $\mathrm{n}^{\circ} \quad 40,11$ de febrero de 1888) o el muelle de Salaverry El Perú Ilustrado, $\mathrm{n}^{\circ} 26,5$ de noviembre de 1889) son algunas de las obras cuya existencia es revelada a los lectores domiciliados a lo largo y ancho del país: "[Ese] camino [...] una vez terminado, del modo más cómodo y seguro para el tráfico, debe influir provechosamente en el desarrollo del comercio y de la industria en esa apartada región de nuestro territorio, tan espléndidamente dotada por la naturaleza". A veces las fotos fueron tomadas por entusiastas aficionados que durante varias semanas enviaron a la revista vistas inéditas desde provincias casi inaccesibles pero por lo general dotadas de riquezas mineras aún sin explotar.

La nota que acompaña los grabados suele ser más concisa que las biografías que corresponden a los retratos, porque los redactores limeños disponían de muy poca información sobre el asunto representado. La proeza técnica siempre está puesta de relieve, como en el caso del paso del Infiernillo calificado de "obra maestra en su género" y fotografiado por el director de la revista en persona (El Perú Ilustrado, $\mathrm{n}^{\circ} 26$, 5 de noviembre de 1889). Con este túnel, afirma la revista, "la ciencia ha vencido a la naturaleza [...] la vía férrea cruza tan rápidamente los Andes como baja hasta el fondo del abismo, y allí donde antes sólo se podían oír los tristes lamentos de las llamas resuenan ahora los silbidos alegres y poderosos de la locomotora, como anuncio de paz y progreso". Los elementos de este comentario parecen estar evocando la primera carátula de El Perú Ilustrado que probablemente haya sido creada en función de las instrucciones del propio Bacigalupi.

La fotografía ya no era una novedad en el Perú desde que en los años 1860 Lima vio instalarse fotógrafos europeos y venderse todo tipo de material fotográfico; la reproducción de las imágenes en la prensa en cambio era aún una técnica en ciernes. Por la mala calidad de los primeros fotograbados los litógrafos de El Perú Ilustrado fueron obligados a hacer numerosos retoques, de manera que el dibujo hecho a partir de una fotografía fue lo que se publicó en adelante con la firma del artista. Con la pretensión de darle al grabado un toque natural se agregaba uno que otro peregrino personaje a las fotos de construcciones industriales y locales comerciales olvidándose algunas veces los efectos de perspectiva.

A lo largo de las páginas de la revista ilustrada, el Perú es presentado como un país en plena revolución industrial. La evocación de fábricas y empresas modernas confirma la idea del progreso económico, por eso ocupan un lugar de honor en la revista. Es el caso de la empresa de harinas del norteamericano Milnes (El Perú Ilustrado, n 2, 21 de mayo de 1887), establecida en Chorrillos en 1875, de la destilería Boza en Pisco, de la fábrica francesa de cigarrillos creada en 1869 (El Perú Ilustrado, n 7, 25 de junio de 1887), etc. El exterior de las empresas es reproducido con la intención de poner de relieve una arquitectura que puede ser imponente o funcional. Una locomotora y numerosos vagones 
delante de la fábrica de harinas sugieren una intensa actividad. El límite entre la información y la publicidad casi no existe, los méritos del producto fabricado forman parte de la nota que acompaña el grabado y un anuncio publicitario, unas páginas más adelante, explica cómo adquirir aquellos símbolos de la modernidad o de la elegancia (19). El lector es considerado como un comprador potencial al que la revista presenta las últimas novedades, ya sean productos de importación o fabricados en el país bajo patente extranjera.

Mostrar el interior de las empresas se convierte en la mejor prueba de los adelantos técnicos. La refinería de Zorritos es un buen ejemplo de ese tipo de tratamiento gráfico ya que se le dedican cuatro grabados (El Perú Ilustrado, n $^{\circ} 110,15$ de junio de 1889): una imagen parcial de un cobertizo con enormes depósitos, los pozos de petróleo, un grupo de ingenieros que posa al lado de una prensa y en la última página la vista panorámica de las instalaciones. El único problema consiste en la ausencia de explicaciones, que sólo figuran en el número siguiente poniendo en evidencia hasta qué punto los redactores de la revista desconocen el tema tratado ya que las imágenes no coinciden con los textos (20). Esta impresión se acentúa al leer finalmente el comentario ya que la fabricación de los barriles es considerada como más importante que la extracción del petróleo, una fuente de energía que no parece suscitar el entusiamo de los redactores (21).

La divulgación del conocimiento científico se halla limitada por la escasa formación académica de los redactores de la revista que se contentan con repetir las informaciones vertidas por los corresponsales a veces alejados (22). El Perú Ilustrado muestra también a sus lectores el complejo de hilados de Vitarte, próximo a Lima ( $E l$ Perú Ilustrado, $\mathrm{n}^{\circ}$ 123, 14 de setiembre de 1889). Dos panorámicas de la empresa representan en el primer término la maquinaria; en la primera se aprecian las devanadoras y en la segunda los motores a vapor. Como lo indican las leyendas, las imágenes no precisan comentarios para poner de relieve el alto nivel técnico alcanzado por la empresa, que ha llegado a suprimir la intervención humana.

La confusión entre discurso informativo y mensaje publicitario es evidente en el caso de la cervecería Backus y Johnston, sociedad industrial de la que Bacigalupi forma parte y que presenta un almanaque mensual en la última página de El Perú Ilustrado: reproduce una escena humorística en la que aparecen dos sacerdotes casi ebrios junto a dos pequeños grabados en los que figura una serie impresionante de barriles y el

(19) Después de la presentación de la fábrica de cigarrillos Pouchan viene un aviso publicitario que saca provecho de la situación política del momento: "El general Cáceres es el mejor cigarrillo de elaboración nacional".

(20) El autor de las fotos había previsto enseñar primero los depósitos, luego la vista panorámica, y después vendrían la fábrica de los barriles y los pozos.

(21) Sin embargo El Perú Ilustrado presenta en múltiples oportunidades modelos de lámparas de petróleo en venta en los mismos almacenes Bacigalupi. También abundan las publicidades de máquinas de coser, aparatos fotográficos, teléfonos a batería y demás artículos importados por Bacigalupi.

(22) En los mismos años, precisamente en 1888 fue fundada la Sociedad Geográfica de Lima que había de hacer estudios geográficos y coleccionar todo tipo de escritos relacionados con la geografía del Perú con el fin de defender los derechos territoriales amenazados por los países vecinos $\mathrm{y}$ fomentar el desarrollo nacional. 
exterior de la empresa. Mucho ruido y pocas nueces ya que el comentario que antecedía al almanaque anunciaba una imagen de la tecnología más avanzada puesta en obra:

"Cuando el visitante penetra al interior de la fábrica y ve las grandes maquinarias para la elaboración de la cerveza y del hielo, cuenta el considerable número de operarios que ahí tienen labor constante, y nota que hasta la última dependencia de la fábrica está alumbrada por electricidad, producida por un magnífico dinamo colocado en uno de los salones del piso bajo, siéntese presa de verdadera admiración, duda por un momento de que es en el Perú en donde se halla y concluye por bendecir a esas deidades sublimes que se llaman Industria y Trabajo, cuyo culto que ha hecho desaparecer las distancias, acabará por borar [sic] las fronteras entre los pueblos que les erijan altares." (El Perú Ilustrado, n 113, 6 de julio de 1889)

Al contemplar ese calidoscopio de paisajes, monumentos y empresas, el lector de El Perú Ilustrado tiene la impresión de recorrer el territorio nacional, desde el norte gracias al petróleo y sus derivados, hasta el sur bajo dominación chilena. Los Andes ya no forman una barrera gracias al desarrollo de los túneles, vías férreas y puentes litografiados con orgullo como las obras de arte de una nueva era que va a reunir todos los pueblos del Perú. De esta manera, la imagen desempeña un papel integrador para el público provinciano y capitalino.

\section{ENSEÑAR DELEITANDO}

La rúbrica "Tipos Populares" completa el panorama ofrecido por El Perú Ilustrado. Se ubica en la última página y como en las revistas españolas que sirvieron de modelo, se trata de proponer amenidades y dibujos entre curiosos y graciosos. Así es como los pobladores de la Amazonía, las comunidades andinas y los trabajadores modestos de la Costa quedan relegados en esa página de cierre, al lado de ilustraciones de una fauna real o imaginaria.

Tapires, armadillos y otras especies exóticas figuran allí al lado de un entretenido jeroglifo: están representados en su medio natural, en una posición que ha de permitir apreciar todas las características morfológicas. La imagen ocupa la mitad de una página y puede ser coleccionada en un álbum. El nombre del animal no siempre figura en la nota explicativa, pero sí la firma del dibujante, cuyo nombre anglosajón, las más de las veces aparece como una garantía de seriedad para el público peruano.

Lamentablemente, a veces, los comentarios son sólo el fruto de una imaginación caprichosa, así como los datos científicos que los acompañan: en El Perú Ilustrado se puede contemplar una serpiente marina, que emerge a treinta millas de las costas de América; mito o realidad, en todo caso, la imagen de ese malmirado pejesapo se yergue en el grabado sin tomar en cuenta ni las proporciones ni la perspectiva (El Perú Ilustrado, $\mathrm{n}^{\circ} 4,4$ de junio de 1887).

Los defectos se acentúan en las ilustraciones consagradas a los pueblos de la Amazonía peruana, sacadas del libro de Carlos Fry. Los indios son siempres minúsculos, 
ya sea al interior de sus piraguas o en la cima de los árboles, donde viven como simios. Desnudos, poco agraciados e infantiles, a lo más que pueden aspirar es a servir de guías al explorador que busca un camino para unir la costa a la selva (Fig. 4):

“[Fry quiso] probar la viabilidad de los caudalosos ríos [...] y las facilidades que ahí tiene la civilización para llevar su gloriosa enseña hasta los últimos confines del opulento territorio que la naturaleza nos designara", (El Perú Ilustrado, n ${ }^{\circ}$ 111-112, 22 y 29 de junio de 1889).

Tal serie de imágenes tiene como única perpectiva la conquista de los territorios orientales del Perú descuidados por las autoridades públicas. La pérdida de las provincias salitreras ha de ser compensada con el descubrimiento del nuevo El Dorado,

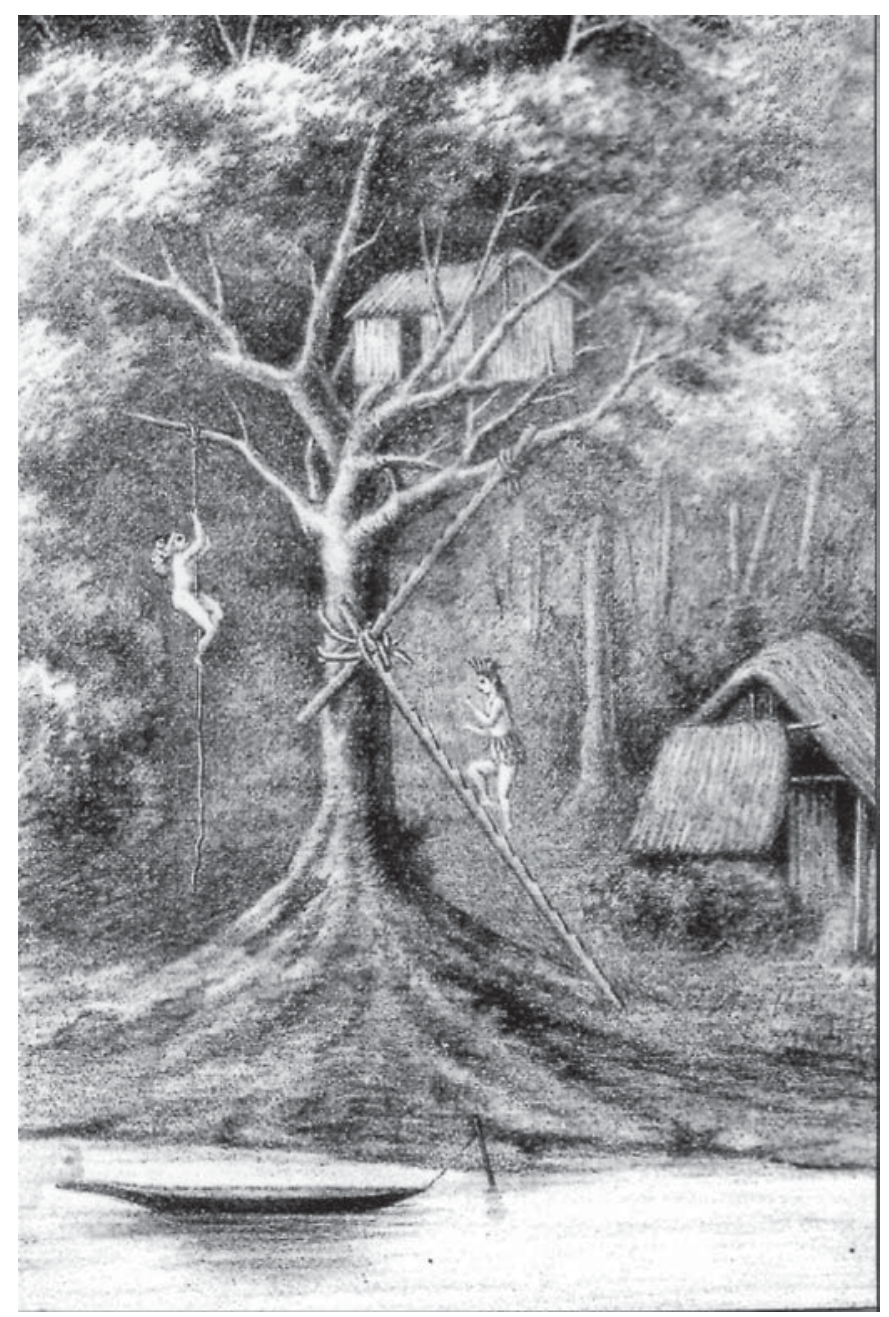

Fig. 4 - El Perú Ilustrado, nº 112, 29 de junio de 1889. 
hacia donde se envían desde 1885 numerosas expediciones. El Perú Ilustrado al publicar los grabados pretende contribuir con ese sueño, poblado de espacios casi vírgenes donde parece fácil hacer fortuna.

La representación de las comunidades andinas conlleva el mismo exotismo pero carece por completo de todo tipo de estímulo. El rostro de un grupo de bailarines bolivianos con trajes emplumados refleja la degeneración de la raza (Fig. 5). El comentario se limita a criticar el alcoholismo y el mal gusto de las fiestas. Al abordar así estos temas, sólo se puede llegar a una conclusión: el indio es un ser repugnante y degenerado, sea el de la Amazonía o el de los Andes, y por ende, condenado a figurar sistemáticamente en la última página (23). Lo mismo sucede con las personas modestas de las ciudades, dibujadas siempre de manera caricaturesca como el deforme cochero limeño (El Perú Ilustrado, n 4, 4 de junio de 1887), o el tamalero montado en innoble burro (El Perú Ilustrado, n 7,25 de junio de 1887). La simplificación y a veces el exceso caracterizan esos dibujos tan diferentes de los cuidadosos retratos de la primera plana consagrados a las personas célebres, modelos para todo el país. De forma casi imperceptible El Perú Ilustrado establece una jerarquía marginalizando a la inmensa

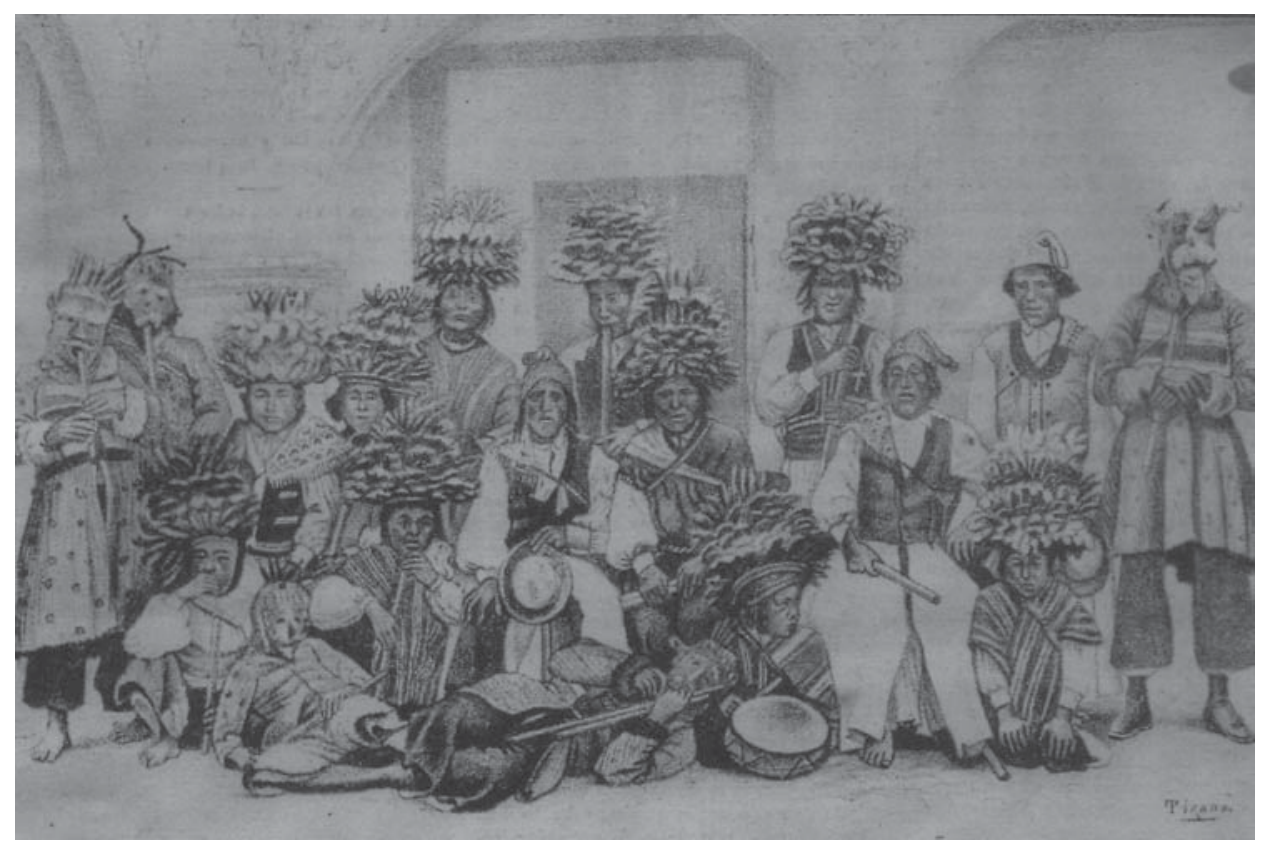

Fig. 5 - El Perú Ilustrado, ${ }^{\circ}$ 127, 12 de octubre de 1889.

(23) Tal discurso, que coincide con las afirmaciones de la antropología social desarrollada por Gustavo Le Bon en sus difundidas Leyes psicológicas de la evolución de los pueblos (1884), y con las tesis de la antropología criminal de Lombroso, contrasta con los llamamientos de Manuel González Prada para despertar al indio, "[sacudiendo] con rudeza brutal a esos hombres soñolientos que perdurablemente cabecean en las faldas de la Gran Cordillera” (Pájinas libres: 1894, 147-161). 
mayoría de peruanos a los que no considera dignos de representar al país. El modelo que seguir es la pujanza norteamericana, promesa de prosperidad.

La diversidad de temas tratados en la revista de Bacigalupi nos lleva a formular dos conclusiones opuestas. La quietud de los rostros y la perfección de los retratos se explican por la labor de los dibujantes que trabajaron hasta borrar los defectos físicos; pese a esos retoques halagüeños, por la cantidad de información aportada, El Perú Ilustrado sigue siendo una fuente excepcional sobre la vida pública a finales de los años 1880 .

La representación de paisajes y objetos no obedeció a los mismos planes, tratándose más bien de dar a conocer que de celebrar. La objetividad pasó a ser un dogma, con el fin de ofrecer al lector un documento iconográfico tan valioso como si fuera una fotografía, considerada en aquel entonces como paradigma de la imparcialidad y el realismo. La elección de los lugares y de los monumentos es reveladora del afán de integrar las regiones ricas y aisladas y presentar un país dinámico, secreta cornucopia al alcance de los hombres emprendedores. Se niegan las destrucciones ocasionadas por la guerra; prevalece el optimismo.

Sin embargo, la voluntad inicial de estimular la cultura asociando imagen y lectura fue víctima de su propio éxito pues las ambiciones comerciales se fueron adelantando a la información y El Perú Ilustrado cedió un espacio cada vez mayor a los avisos económicos (24). Tal traición de los objetivos y la crisis de 1890 (cf. nota 2) favorecieron la publicación de otras revistas rivales tituladas La Ilustración americana, La Revista Americana, El Perú Artístico. Pero ninguna consiguió tanta ganancia y careciendo del sentido de los negocios de un Bacigalupi, tuvieron una vida más efímera que El Perú Ilustrado (25).

\section{Referencias citadas}

El Perú Ilustrado: años 1887-1892 (Biblioteca Nacional del Perú).

La prensa ilustrada en España-Las Ilustraciones 1850-1920, 1996 - Montpellier: Iris-Université de Montpellier, $350 \mathrm{p}$.

GONZALEZ PRADA, M., 1894 - Pájinas libres, 271p.; Paris: Paul Dupont.

TAUZINCASTELLANOS, I., 1990 - Le roman féminin péruvien dans la seconde moitié du XIXe siècle. Thèse de Doctorat, Université de Poitiers, 525p.

(24) En 1890 de un total de 35 páginas, más de 15 estaban conformadas por anuncios y sólo 4 correspondían a las ilustraciones.

(25) El Perú Ilustrado tuvo una segunda época, en 1896 cuando el poeta José Santos Chocano retomó el título para una revista bimensual dedicada a las artes y desvinculada de la realidad nacional. 